\title{
Analisis Kemampuan Representasi Matematis Mahasiswa Berdasarkan Motivasi Belajar
}

\author{
Yenni $^{*}$ dan Rika Sukmawati ${ }^{2}$ \\ 1*,2Pendidikan Matematika, Universitas Muhammadiyah Tangerang \\ Jalan Perintis Kemerdekaan 1/33, Tangerang, Banten, Indonesia \\ 1*yennisaja@outlook.com;2rikasukma75@yahoo.com
}

Artikel diterima: 27-12-2019, direvisi: 10-02-2020, diterbitkan: 31-05-2020

\begin{abstract}
Abstrak
Penelitian ini bertujuan mendeskripsikan kemampuan representasi mahasiswa berdasarkan level motivasi mahasiswa. Metode yang digunakan adalah kualitatif deskriptif. Instrumen yang digunakan adalah tes dan non tes. Tes terdiri dari soal-soal yang menuat indikator representasi matematis, sedangkan non tes berupa angket motivasi belajar dan pedoman wawancara. Subjek penelitian adalah mahasiswa program studi PGPAUD Universitas Muhammadiyah Tangerang kelas 3A2, yang berjumlah 29 mahasiswa. Hasil penelitian menunjukkan, tidak ada mahasiswa yang memiliki motivasi belajar level rendah. Sebanyak $55,17 \%$ mahasiswa dapat menjawab dengan baik untuk indikator menyajikan data dalam berbagai bentuk. Sedangkan pada indikator penyimbolan terdapat 44,83\%. Mahasiswa dengan motivasi tinggi mampu menyelesaikan permasalahan matematika pada statistika dengan baik sesuai yang diharapkan. Sedangkan pada mahasiswa dengan motivasi sedang, terungkap mahasiswa kurang teliti dalam mengerjakan soal sehingga menyebabkan skor yang diperoleh tidak sempurna.

Kata Kunci: kemampuan representasi matematis, motivasi belajar, statistika, kualitatif deskriptif.
\end{abstract}

\section{Analysis of Students' Mathematical Representation Ability Based on Learning Motivation}

\begin{abstract}
This study aims to describe the ability of student representation based on the level of student motivation. The method used is descriptive qualitative. The instruments used were tests and non-tests. The test consisted of questions that raised mathematical representation indicators, while the non-test consisted of a learning motivation questionnaire and interview guidelines. The research subjects were students of the PGPAUD study program at the Muhammadiyah University of Tangerang in class 3A2, totaling 29 students. The results showed that there were no students who had a low level of motivation to learn. As many as $55.17 \%$ of students can answer well for indicators presenting data in various forms. While the symbolic indicators are $44.83 \%$. Students with high motivation can solve mathematical problems in statistics as well as expected. While the students with moderate motivation, it was revealed that the students were less thorough in working on the problems so that the scores obtained were not perfect. Keywords: kemampuan mathematical representation, learning motivation, statistics, descriptive qualitative.
\end{abstract}




\section{Pendahuluan}

Penelitian ini bertujuan untuk mendeskripsikan kemampuan representasi mahasiswa berdasarkan motivasi belajar mahasiswa pada matakuliah statistika. Banyak hal yang melatarbelakangi permasalahan representasi mahasiswa (Damayanti \& Afriansyah, 2018). Pada penelitian ini, penelitian dikhususkan, bahwa kemampuan representasi juga dapat menjadi akibat dari kurangnya motivasi belajar terutama pada mata kuliah statistika.

Setelah mempelajari suatu materi, tentu peserta didik diharapkan dapat menguasai materi yang diberikan. Keberhasilan peserta didik dalam menjawab dan menyelesaikan masalah menjadi salah satu indikator bahwa proses pembelajaran berhasil (Nuraeni \& Afriansyah, 2016). Namun, kondisi peserta didik yang beragam memberikan hasil yang beragam pula. Hal ini dapat ditelusuri dengan melihat hasil pekerjaan peserta didik dalam menyelesaikan permasalahan. Salah satu hal penting yang berperan dalam keberhasilan menyelesaiakan permasalahan dalam matematika adalah kemampuan representasi matematis.

Representasi diartikan sebagai suatu tindakan dalam memahami apa yang didapat dan memaknai bentuk gambar dalam model apapun melalui kata-kata dan dapat mengatakan apa saja yang ingin dikatakan (Puspandari, Praja, \& Muhtarulloh, 2019). Senada dengan pendapat tersebut, Metlzer (2000) mengungkapkan bahwa representasi merupakan suatu model dalam bentuk yang luas dan bervariasi sehingga suatu konsep dapat dipahami dan dikomunikasikan dalam bentuk lain yang berupa simbol. Dapat dikatakan, bahwa seseorang dapat mengartikan, mengungkapkan, dan mengekspresikan suatu hal sesuai dengan bentuk yang paling dikuasai. Hal ini seharusnya tidak sulit karena sejatinya setiap orang memiliki salah satu kecenderungan kemampuan (Afriansyah, 2016).

Frena (2017) mengatakan bahwa representasi merupakan suatu ketrampilan yang harus dimiliki oleh mahasiswa dalam mempelajari statistika. Materi Statistika menuntut mahasiswa agar dapat menyelesaikan masalah statistika dalam berbagai bentuk representasi. Tentu semua memerlukan proses. Proses yang terarah dan tepat sarasan akan memaksimalkan hasil. Demikian pula dengan kemampuan representasi matematis. Kemampuan ini akan maksimal jika disediakan sarana yang sesuai. Salah satunya berupa latihan rutin.

Goldin dan Kaput (2016) berpendapat bahwa representasi merupakan konfigurasi dari pemikiran seseorang secara menyeluruh atau terbagi-bagi yang terhubung satu dengan lain secara simultan. Masih merujuk pendapat Goldin dan Kaput, representasi matematis terbagi dua bagian, yakni representasi internal dan representasi eksternal (2015). Representasi internal mengarah pada 
konfigurasi mental secara individual baik pada diri siswa maupun bagi problem solvers. Karena representasi internal merupakan konfigurasi mental tentu saja tidak dapat diamati secara langsung. Sebagai seorang guru atau peneliti secara teratur dapat menyimpulkan konfigurasi mental siswa melalui hasil pengamatan terhadapa apa yang dilakukan siswa dan apa yang mereka katakan. Apa yang dilakukan dan dikatakan siswa disebut dengan representasi eksternal. Seringkali guru/peneliti membuat kesimpulan tentang keadaan siswa secara diam-diam dan bukan secara eksplisi. Guru secara sadar mulai mengembangkan representasi internal tertentu pada siswa melalui aktivitas mengajar (Annajmi \& Afri, 2019). Pentingnya representasi sistem representasi secara kognitif dalam model Goldin digunakan untuk merencanakan, memantau, dan mengendalikan proses pemecahan masalah matematis. Representasi dalam komunikasi matematis dapat membantu proses penyempurnaan pemahaman ide-ide matematika, serta membantu membangun arti dan kekekalan suatu ide. Jika siswa diberikan tantangan untuk berpikir dan bernalar tentang matematika serta mengomunikasikan hasil pemikirannya secara lisan dan tulisan, maka dengan bantuan representasinya siswa akan dapat memperoleh pemahaman yang semakin jelas dan meyakinkan.

Permasalahan

kemampuan representasi matematis telah dijumpai saat peserta didik berada di usia Sekolah Menengah Pertama (SMP). Salah satunya temuan oleh Wilujeng dan Yenni (2016), bahwa peserta didik pada kecerdasan tertentu tidak sama dalam menyelesaikan permasalahan representasi matematis. peserta didik dengan kecerdasan jenis linguistik, spasial dan logis matematis berbeda dalam mengungkapkan jawaban pemasalahan matematis. Demikian pula dengan peserta didik usia Sekolah Menengah Atas (SMA). Permasalahan representasi ditemukan dalam materi Trigonometri. Temuan oleh Izwita dkk (2017) pada peserta didik laki-laki terdapat permasalahan perhitungan yang tidak tepat sebagai akibat kurang tepatnya peserta didik dalam membuat sketsa gambar dan menempatkan keterangan. Demikian pula pada peserta didik perempuan. Peserta didik kurang tepat menjawab sebagai akibat dari tidak tepat dalam menggunakan konsep saat menyelesaiakan masalah.

Representasi merupakan hal yang tidak bisa dipisahkan dalam pembelajaran matematika (Muzaki \& Masjudin, 2019). Meskipun tidak tercantum secara tersurat dalam tujuan pembelajaran matematika di Indonesia, namun secara tersirat pentingnya representasi terlihat pada tujuan pemecahan masalah dan komunikasi matematika, karena untuk menyelesaikan masalah matematis, diperlukan kemampuan membuat model matematika dan menafsirkan solusinya 
yang merupakan indikator representasi (Fatrima, 2017).

Juanita (2016) mengatakan bahwa kemampuan representasi matematis diperlukan untuk menyajikan berbagai macam gagasan atau ide matematis yang diterimanya. Bentuk representasi dalam menyelesaikan masalah dapat dalam bentuk menggambarkan, menuliskan dan memodelkan gagasan (Ramziah, 2016). Artinya, bahwa seseorang akan dapat memanipuasi dan mengunakan kemampuannya dalam menyelesaikan permasalahan matematika berdasarkan pengetahuannya. Dalam pengertian yang paling umum, representasi adalah suatu konfigurasi yang dapat menggambarkan sesuatu yang lain dalam beberapa cara (Goldin, 2002, p.208).

Pada penelitian ini, indikator dari representasi matematis adalah menggambarkan, menyimbolkan gagasan kembali objek matematika yang telah diketahui sebelumnya. Keberhasilan dalam memperoleh kemampuan representasi matematis yang maksimal ditentukan oleh banyak faktor. Diantaranya faktor internal dan eksternal. Warti (2016) mengungkapkan bahwa Ada dua faktor keberhasilan untuk mencapai hasil yang baik antara lain:

1) Faktor intelegensi. Faktor intelegensi sering diartikan sebagai kepintaran bawaan dari individu. Yaitu kemampuan seseorang untuk menyesuaikan diri dengan baik dalam situasi yang dihadapi. Seorang anak dengan mudah menyelesaikan masalah atau dapat menyesuikan diri dengan lingkungan dan belajar dari pengalamannya.

2) Faktor motivasi. Motivasi berperan penting. Pengaruh dari motivasi mengakibatkan dorongan keras, keinginan yang kuat, serta kecenderungan ingin segera meyelesaikan suatu masalah.

Jatmiko (2015) mengungkapkan, pembelajaran yang dilakukan oleh guru tentunya akan berhasil jika didukung oleh siswa yang memiliki sikap positif dan motivasi yang bagus untuk belajar. Lebih tegas diungkapkan Mudjiman (2007), yaitu bahwa kegiatan pembelajaran akan selalu didahului oleh proses pembuatan keputusan-keputusan untuk berbuat atau tidak berbuat. Apabila motivasinya cukup kuat maka seseorang akan memutuskan untuk melakukan kegiatan belajar. Seseorang yang memiliki motivasi cukup kuat untuk terlibat dalam pembelajaran akan memilih tugas sesuai dengan kemampuannya, serta segera memulai kegiatan ketika mendapat kesempatan, dan mengerahkan usaha intensif dan konsentrasi dalam penyelesaikan tugastugas belajar. Sebaliknya, apabila motivasinya tidak cukup kuat maka ia akan memutuskan untuk tidak melakukan kegiatan belajar. Penjelasan Mudjiman sangat jelas, bahwa motivasi sangat diperlukan, serta menentukan keberhasilan dalam menjalani suatu hal.

Motivasi adalah kemauan, kehendak, keinginan, daya yang mendorong seseorang untuk melakukan sesuatu. Para 
ahli banyak perpendapat bahwa motivasi sangat penting untuk keberhasilan siswa belajar. W.S Winkel (1987) menyatakan motif adalah daya penggerak dari dalam subjek untuk melakukan aktifitas-aktifitas tertentu demi mencapai suatu tujuan. H.J.M Hermans menyebutkan bahwa cirriciri orang yang mempunyai motivasi adalah: (1) Kecendrungan mengerjakan tugas-tugas yang menantang namun tidak berada diatas kemampuannya; (2) Keinginan untuk berusaha dan bekerja sendiri serta menemukan penyelesaian sendiri; (3) Keinginan kuat untuk maju dan mencapai taraf keberhasilan yang sedikit diatas taraf yang dicapai sebelumnya; (4) Orientasi pada masa depan, kegiatan belajar dipandang sebagai jalan menuju realisasi cita-cit; dan (5) Keuletan dalam Bekerja.

Motivasi seseorang untuk melakukan suatu kegiatan pada proses pembelajaran dipengaruhi oleh faktor internal dan eksternal. Fator tersebut lebih dikenal dengan istilah motivasi intrinsik dan motivasi ekstrinsik. Arends \& Kilcher (2010) dan Wookfolk (2007) menyatakan motivasi ekstrinsik adalah tindakan individu melakukan tindakan untuk mendapatkan hadiah yang diinginkan. Motivasi ekstrinsik didasarkan pada faktorfaktor yang tidak berhubungan dengan kegiatan itu sendiri, siswa tidak benarbenar peduli dalam kegiatan untuk kepentingan dirinya sendiri, siswa hanya peduli terhadap apa yang didapatkan dari kegiatan tersebut. Indikator motivasi intrinsik dan motivasi ekstrinsik dapat disimpulkan berdasarkan pendapat Uno (2011) bahwa motivasi adalah dorongan internal dan eksternal dalam diri seseorang untuk mengadakan perubahan tingkah laku,yang mempunyai indikator sebagai berikut: (1) adanya hasrat dan keinginan untuk melakukan kegiatan; (2) adanya dorongan dan kebutuhan melakukan kegiatan; (3) adanya harapan dan cita-cita; (4) penghargaan dan penghormatanatas diri; (5) adanya lingkungan yang baik; dan (6) adanya kegiatan yang menarik.

Dalam bahasa lain, motivasi merujuk pada usaha seseorang dalam melakukan sesuatu berdasarkan hal yang disukai, untuk meraih sesuatu secara sukses. Indikator motivasi yang diteliti pada penelitian ini adalah: (1) keinginan untuk melakukan kegiatan; (2) keyakinan untuk suskses; (3) keuletan dalam berusaha.

\section{Metode}

Jenis Penelitian ini adalah kualitatif deskripstif yang bertujuan untuk menggambarkan kemampuan representasi mahasiswa dalam menyelesaikan permasalahan pada mata kuliah statistika.

Subjek penelitian yaitu mahasiswa program studi pendidikan guru pendidikan anak usia Dini (PGPAUD), yang seluruhnya terdiri dari 29 mahasiswa. Namun, agar memperoleh informasi yang lebih valid, subjek mahasiswa akan dipilih sesuai dengan data angket motivasi belajar yang diperoleh pada hasilpenelitian. 
Instrumen penelitian utama adalah peneliti dengan berbatuan instrument angket, tes dan pedoman wawancara. Jenis instrument ini sejalan dengan teknik pengumpulan data yang dipergunakan. Metode pengumpulan data yang dipergunakan yaitu:

1) Teknik pertama adalah metode tes. Metode ini menggunakan instrumen tes yang digunakan untuk mengukur kemampuan representasi matematis mahasiswa. Langkah-langkah dalampengambilan data meliputi: (1) menyiapkan soal; (2) membagikan soal kepada mahasiswa; (3) Mengawasi mahasiswa dalam menyelesaikan soa; (4) memeriksa hasil pekerjaan mahasiswa; (5) mengevaluasi; menganalisa hasil tes.

2) Metode non tes

Metode non tes yang dipergunakan dalam penelitian ini terdapat dua cara yaitu membagikan angket dan pedoman wawancara. Angket digunakan untuk memperoleh data motivasi mahasiswa dalam mengikuti perkuliahan statistika. Sedangkan pedoman wawancara digunakan untuk memperoleh data lebih jelas dan mendalam, tentang hal-hal yang tidak terlihat atau tidak diperoleh dalam tes kemampuan represtasi dan angket motivasi.

Instrumen motivasi belajar statistika yang diberikan kepada mahasiswa berupa pernyataan positif dan negative. Terdapat lima pilihan jawaban, yaitu Sangat Setuju
(SS), Setuju (S), Ragu-ragu (R), Tidak Stuju (TS) serta Sangat Tidak Setuju (STS). Mahasiswa diharuskan memberikan tanda cek (V) pada salah satu jawaban pada alternatif jawaban yang disediakan. Adapun skor pernyataan pada angket sebagai berikut.

Tabel 1.

Skor Angket Motivasi Belajar

\begin{tabular}{lll|}
\hline Alternatif jawaban & $\begin{array}{l}\text { Item } \\
\text { positif }\end{array}$ & $\begin{array}{l}\text { Item } \\
\text { negatif }\end{array}$ \\
\hline Sangat Setuju (SS) & 5 & 1 \\
\hline Setuju (S) & 4 & 2 \\
\hline Ragu-ragu (R) & 3 & 3 \\
\hline Tidak Setuju (TS) & 2 & 4 \\
\hline $\begin{array}{l}\text { Sangat Tidak Setuju } \\
\text { (STS) }\end{array}$ & 1 & 5 \\
\hline
\end{tabular}

Klasifikasi motivasi belajar dihitung berdasarkan jumlah pernyataan dan alternative jawaban (Arifin, 2010). Angket motivasi terdiri dari 44 pernyataan dengan lima alternatif jawaban. Pada penelitian ini motivasi akan diklasifikasi menjadi tiga level yaitu tinggi, sedang, dan rendah. Berdasarkan perhitungan, diperoleh interval sebagai berikut:

Tabel 2.

Interval dan Level Motivasi Belajar

\begin{tabular}{ll}
\hline Interval & Kategori \\
\hline $162-220$ & Tinggi \\
\hline $103-161$ & Sedang \\
\hline $44-102$ & Rendah
\end{tabular}

Teknik analisis data deskriptif kualitatif dengan tahapan sebagai berikut:

1. Reduksi data. Reduksi data dilakukan untuk membuang data yang tidak perlu. 
Tujuannya agar data yang dianalisis lebih tajam.

2. Penyajian data. Segala informasi yang diperoleh dari subjek penelitian dikemas, dan disajikan agar lebih praktis dan mudah terbaca.

3. Kesimpulan. Tahap ini merupakan intisari lanjutan dari tahap reduksi data dan penyajian data yang telah diorganisasi dengan bentuk pernyataan kalimat yang singkat dan padat, namun memiliki pengertian yang luas.

\section{Hasil dan Pembahasan}

Berikut ini adalah hasil penelitian yang dirangkum untuk menjawab tujuan penelitian.

\section{A. Data Motivasi Mahasiswa pada mata kuliah Statistika}

Anget motivasi belajar terbagi dalam tiga Aspek, yaitu: (1) keinginan untuk melakukan kegiatan; (2) keyakinan untuk sukses; dan (3) keuletan dalam berusaha. Jumlah pernyataan angket adalah 44. Hasil rekap jawaban 29 mahasiswa pada angket motivasi belajar sebagai berikut:

Tabel 3

Hasil rekap angket dari 29 mahasiswa

\begin{tabular}{|c|c|c|c|c|c|}
\hline Aspek & Indikator & $\begin{array}{l}\text { Jumlah } \\
\text { Pernyat } \\
\text { aan }\end{array}$ & Skor & $\begin{array}{l}\text { Skor } \\
\text { total }\end{array}$ & $\begin{array}{l}\text { Rata- } \\
\text { rata }\end{array}$ \\
\hline $\begin{array}{l}\text { Keingi } \\
\text { nan } \\
\text { melak } \\
\text { ukan } \\
\text { kegiat } \\
\text { an }\end{array}$ & $\begin{array}{l}\text { Tertarik pada } \\
\text { mata } \\
\text { pelajaran } \\
\text { tertentu } \\
\text { Rajin mencari } \\
\text { informasi } \\
\text { tentang } \\
\text { pelajaran }\end{array}$ & 4 & 454 & 944 & 4,07 \\
\hline $\begin{array}{l}\text { Keyaki } \\
\text { nan } \\
\text { untuk } \\
\text { sukses }\end{array}$ & $\begin{array}{l}\text { Gambaran } \\
\text { Keberhasilan } \\
\text { Membuat } \\
\text { Rencana } \\
\text { Kemandirian }\end{array}$ & $\begin{array}{l}4 \\
4 \\
4\end{array}$ & $\begin{array}{l}424 \\
468 \\
464\end{array}$ & 2779 & 3,99 \\
\hline
\end{tabular}

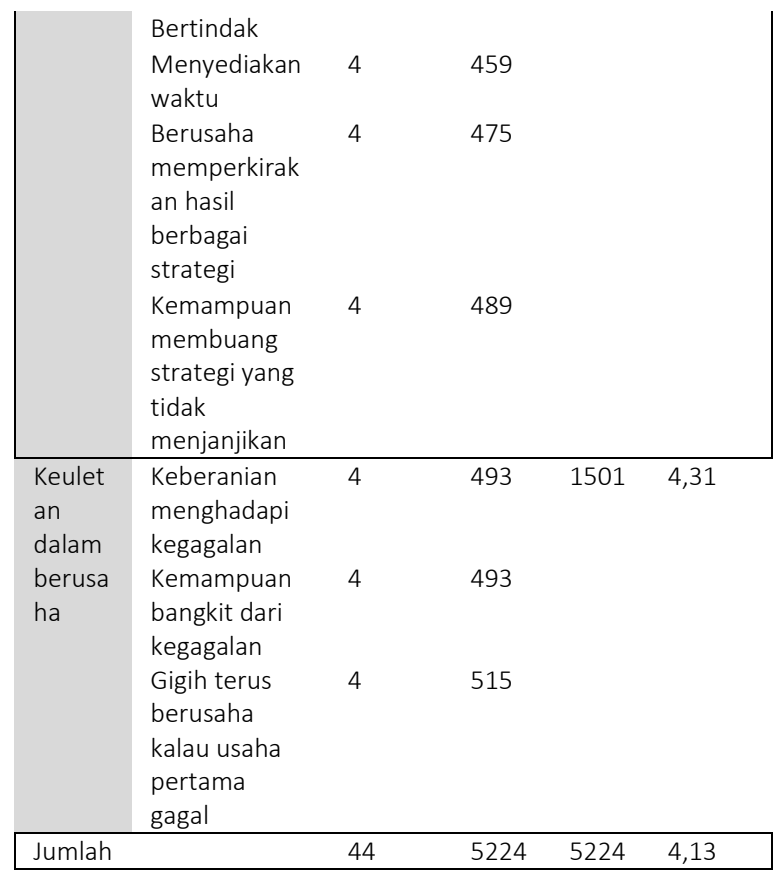

Berdasar tabel 3 dapat dilihat, secara keseluruhan semua aspek berada pada katagori baik. Nilai Indikator tertinggi berada pada aspek keuletan dalam berusaha, disusul aspek keinginan melakukan kegiatan dan terakhir aspek keyakinan untuk sukses.

Selanjutnya, akan disajikan skor jawaban angket per individu mahasiswa.

Tabel 4

Skor Maksimal dan Minimal Angket Motivasi

\begin{tabular}{llll}
\hline Keterangan & Skor & jumlah & Persen \\
\hline Skor maksimal & 209 & 26 & 89.7 \\
\hline Skor minimal & 156 & 3 & 10,3 \\
\hline Rata-rata Skor & 180,45 & 29 & 100 \\
\hline
\end{tabular}

Berdasar tabel 4 terlihat bahwa tidak ada mahasiswa dengan motivasi belajar rendah karena semua mahasiswa memiliki skor diatas 102. Berdasarkan tabel 2, maka tidak ada mahasiswa yang memiliki motivasi rendah. Hasil angket mahasiswa seluruhnya masuk ke level tinggi dan 
sedang. Rata-rata motivasi belajar diberikan kepada mahasiswa untuk mahasiswa berada pada skor 180,45. mengumpulkan tugas adalah sehari. Artinya termasuk kategori tinggi. Mahasiswa diwajibkan telah memiliki data Selanjutnya, pemilihan subjek mahasiswa berdasarkan skor motivasi belajar. Dari masing-masing level diambil satu mahasiswa untuk wawancara. Jumlah mahasiswa yang digunakan adalah satu mahasiswa setiap levelnya. Dengan demikian, total dua mahasiswa yang dipilih sebagai perwakilan pengambilan data.

\section{B. Data Nilai Representasi matematis}

Data representasi matematika diperoleh dari hasil tes essay yang dikerjakan oleh mahasiswa. Terdapat dua indikator, yaitu indikator menggambarkan kedalam berbagai bentuk, serta meyimbolkan sesuai dengan ketentuan.

Berikut ini adalah soal yang digunakan untuk mengukur kemampuan representasi mahasiswa.

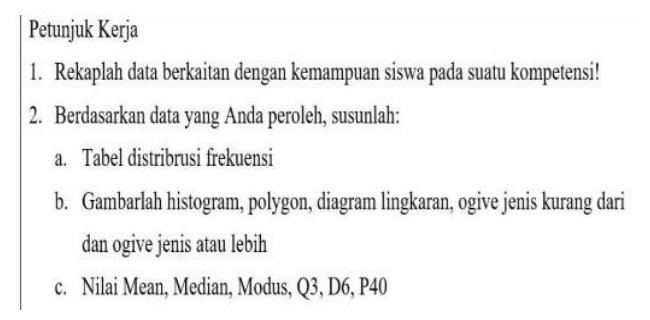

Gambar 1. Soal representasi

Mahasiswa diharuskan telah memiliki dua set data. Mahasiswa menyerahkan tugas dalam bentuk print out. Berdasarkan data yang telah dikumpulkan oleh mahasiswa, selanjutnya mahasiswa diminta untuk menyajikan data ke dalam berbagai bentuk representasi. Waktu yang nilai dari tugas yang diberikan sebelumnya. Menggambarkan dalam berbagai bentuk di ukur melalui nomor $2 a$ dan $2 b$. Kemampuan menyimbolkan diukur melalui nomor 2c serta proses pembuatan table distribusi frekuensi.

Berikut ini deskripsi data nilai mahasiswa pada kemampuan representasi matematis sebagai berikut:

\section{Tabel 5}

Rekap data kemampuan Representasi Mahasiswa

\begin{tabular}{llll|}
\hline Keterangan & \multicolumn{2}{c}{ Indikator } & Total \\
\cline { 2 - 3 } & $\begin{array}{l}\text { Menyajikan } \\
\text { data dalam } \\
\text { berbagai } \\
\text { bentuk }\end{array}$ & Menyimbolkan \\
& 100 & 100 & 100 \\
\hline $\begin{array}{l}\text { Nilai } \\
\text { Maksimal }\end{array}$ & 20 & 30 & 45 \\
\hline $\begin{array}{l}\text { Nilai } \\
\text { Minimum }\end{array}$ & 68,28 & 74,83 & 71,55 \\
\hline $\begin{array}{l}\text { Rata-rata } \\
\text { Jumlah } \\
\text { mahasiswa } \\
\text { dengan nilai } \\
\text { diatas rata- } \\
\text { rata }\end{array}$ & 16 & 13 & 9 \\
\hline $\begin{array}{l}\text { Persen diatas } \\
\text { rata-rata }\end{array}$ & 55,17 & & \\
\hline
\end{tabular}

Berdasarkan total nilai, hanya sembilan mahasiswa yang memperoleh nilai diatas rata-rata kelas. Pada indikator pertama, yaitu menyajikan data dalam berbagai bentuk terdapat 16 mahasiswa yang mendapatkan nilai diatas rata-rata. Sedangkan untuk penyimbolan terdapat 13 mahasiswa yang mendapat nilai diatas rata-rata. 
C. Data Wawancara

Wawancara dilakukan untuk melengkapi data sehingga dapat menggambarkan kemampuan mahasiswa dalam representasi. Selanjutnya masingmasing level dipilih satu subjek untuk wawancara.

1) Hasil wawancara dengan mahasiswa dengan motivasi tinggi (MT)

Sebesar $\quad 89.7 \% \quad$ mahasiswa mendapatkan skor motivasi tinggi. Perwakilan subjek dengan motivasi tinggi adalah mahasiswa dengan skor motivasi tertinggi (MT). Sebelumnya pada table 5 telah diberikan data bahwa skor tertinggi untuk kemampuan representasi adalah 100. MT adalah salah satu mahasiswa yang memperoleh skor 100. MT mampu menjawab dengan baik seluruh permintaan soal.

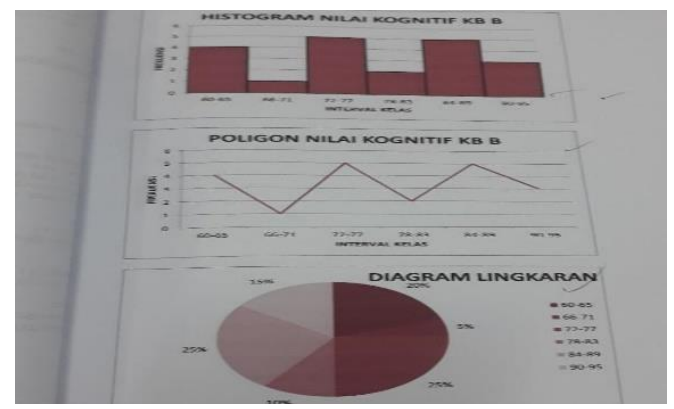

Gambar 2. Jawaban MT

Pada gambar dua terlihat MT mampu mempresentasikan data yang telah dikumpulkannya dalam bentuk table distribusi frekuensi menjadi histogram, polygon, diagram lingkaran, serta ogive. Untuk indikator menyimbolan, MT juga mampu menjawab seluruh permintaan soal dengan benar. Berdasarkan hasil wawancara, MT menagatakan bahwa tidak ada kesulitan dalam menjawab soal statistika yang diberikan.

2) Hasil wawancara dengan mahasiswa dengan motivasi Sedang (MS)

Terdapat 10,3\% mahasiswa dengan motivasi sedang. Tepatnya berjumlah 3 mahasiswa. Dari ketiga mahasiswa tersebut, terdapat mahasiswa dengan skor kemampuan representasi terendah.

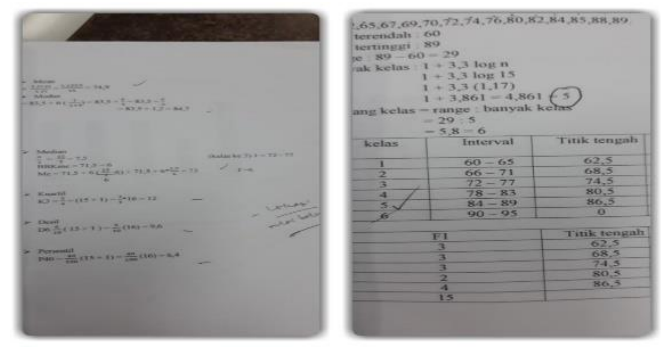

Gambar 3. Jawaban MS

MS mendapat skor 45. Pada kemampuan menyimbolkan, MS salah menempatkan interval dan jumlah kelas pada table distribusi frekuensi. Secara logis, tentu seluruh bentuk representasi akan tidak sama dengan seharusnya. Namun, peneliti masih memberi skor histogram, polygon, diagram lingkaran dan ogive yang dibuat oleh MS dengan catatan sesuai dengan table distribusi frekuensi yang telah di susun.

Selain kesalahan tersebut, MS juga tidak tepat dalam menyimbolkan dan menentukan nilai kuartil dan presentil. 
Petikkan wawancara:

Peneliti = Nilai dari K3, kenapa 12 ?

MS = Berdasarkan hitungan rumus ibu.

Peneliti= baik. Ayo kita cek bersama. Apa yang harus dilakukan saat mencari nilai dari kuarti?

MS = bentar ibu. ljin mengambil buku. (MS ijin mengambil modul di dalam tas jinjing). Ini mencari lokasi ya bu. Setelah ketemu lokasi cari nilainya.

Peneliti= Bagus. Apakah Anda sudah begitu?

MS = Eh... belum selesai ya bu.

Peneliti= Apa yang belum selesai?

MS = iya bu, ini baru sampai nilai tempat.

Peneliti= kenapa Anda mengumpulkan tugas dengan jawaban seperti ini?

MS = saya pikir sudah selesai semua ibu.

MS tidak selesai dalam menentukan nilai dari kuartil, desil dan persentil. Hal tersebut menyebabkan skor pada indicator ini sangat rendah. Factor ketidaktelitian menjadi penyebab utama.

Hasil penelitian mengungkapkan, bahwa dalam penelitian ini mahasiswa dengan motivasi tinggi mampu menyelesaikan permasalahan matematika pada mata kuliah statistika dengan baik sesuai yang diharapkan. Artinya, ada keterkaitan antara motivasi dengan kemampuan representasi matematika. Motivasi yang berdirikan keinginan kuat untuk melakukan sesuatu agar lebih sukses, membuat individu terpacu untuk memperoleh hasil pekerjaan dengan maksimal. Sejalan dengan penelitian Warti (2016) yang mengungkap ada keberartian dan keliniaran antara motivasi belajar dan hasil belajar matematika. Hal ini diungkapkan dengan persamaan $Y=29,65$ $+0,60 X$. Jadi terdapat pengaruh positif antara motivasi belajar dan hasil belajar matematika.

Hasil penelitian Jatmiko (2015) menjelaskan terdapat hubungan positif yang signifikan antara motivasi belajar siswa dengan hasil belajar matematika siswa kelas X SMK NU Pace. Signifikansi ini ditunjukkan oleh hasil uji sig. Sebesar $0,031<0,05$ dan nilai $r \mathrm{xy}=0,322>r$ table $=0,288$. Serta koefisien determinasi menunjukkan bahwa $56,74 \%$ varians motivasi belajar siswa yang terjadi pada hasil belajar matematika. Hal serupa ditemukan pada hasil penelitian Izzati (2009).

\section{Penutup}

Berdasarkan hasil penelitian, maka peneliti menyarankan kepada seluruh pengajar agar senantiasa dapat memotivasi peserta didiknya. Ini sangat penting karena terbukti dapat menumbuhkan keinginan peserta didik ungtuk bisa lebih baik. Terutama kepada pengajar, harus dapat memberikan motivasi kepada peserta didiknya. Memotivasi peserta didik dapat dilakukan diantaranya dengan cara menyampaikan kata-kata sugesti positif, menceritakan kisah inspiratif, serta memodivikasi metode pembelajaran.

\section{UCAPAN TERIMA KasIH}

Ucapan terimakasih peneliti sampaikan kepada Dr. Hairul Saleh, M.Si; Ahmad Fadillah, M. Pd; serta Nurul Fitria 
KD, M. Psi yang telah bersedia memvalidasi instrumen penelitian.

\section{Daftar PUStaka}

Afriansyah, E. A. (2016). The Use of Realistic Approach to Enhance Students' Mathematical Problem Solving Skills. International Conference on Elementary and Teacher Education ICETE.

Annajmi, A., \& Afri, L. E. (2019). Pengaruh Penggunaan Lembar Aktivitas Siswa Berbasis Metode Penemuan Terbimbing terhadap Peningkatan Kemampuan Representasi Matematis Siswa. Mosharafa: Jurnal Pendidikan Matematika, 8(1), 95106.

Arends, R., I., \& Kilcher, A. (2010). Teaching for student learning. New York: Routledge.

Arifin, Z. (2011). Evaluasi Pembelajaran. Bandung: PT Remaja Rosdakarya.

Damayanti, R., \& Afriansyah, E. A. (2018). Perbandingan Kemampuan Representasi Matematis Siswa antara Contextual Teaching and Learning dan Problem Based Learning. JIPM (Jurnal IImiah Pendidikan Matematika), 7(1), 3039.

Fardillah, F. (2017). Kemampuan Representasi Matematis Mahasiswa melalui pembelajaran Cognitive Aperticeship. Jurnal Penelitian dan Pembelajaran Matematika, 10(2), $177-181$.

Fatrima, S. S. (2017). Kemampuan Representasi Matematis dan kemampuan Pembuktian matematika. Jurnal Edumath, 3(1). Januari hal 49-55.

Goldin, G. (2002). Representation in mathematical learning and problem solving. Dalam L. D. English. Handbook Education (197-216). New York, NY: Lawrence Erlbaum Associates

Goldin, G. A., Kaput, J. J. (2015). A Joint Perspective on The Idea of Representation in Learning and Doing Mathematics. ResearchGate. Diakses oktober 2017 dari https://www.researchgate.net/publi cation/269407907

Izwita, D., Saragih, S., \& Khairani, D. (2017). Analisis Peningkatan Kemampuan Representasi Matematis Siswa SMA Ditinjau dari Perbedaan Gender. Jurnal Didaktik Matematika, 4(2), 115-124.

Jatmiko. (2015). Hubungan Motivasi Belajar Dengan Hasil Belajar Matematika Siswa Kelas X SMK Nahdhatul Ulama Pace Nganjuk. Jurnal Math Educator Nusantara, 1(2), 205-213.

Juanita, R. (2016). Kemampuan Representasi dan Komunikasi Matematis Peserta Didik SMA Ditinjau dari Prestasi Belajar dan Gaya Kognitif. Jurnal Pythagoras: Jurnal Pendidikan Matematika, 11(2), 193-206.

Meltzer, D. E (2000). Student learning of Physics Concept: Efficacy of Verval and Written Form od Expression in comparisona to Other Representational Modes. Departemen of Physics and Astronomy, IOWA. State University 
Mudjiman, H. (2007). Belajar mandiri (selfmotovated learning). Surakarta: Lembaga Pengembangan Pendidikan (LPP) \& UPT Penerbitan dan Percetakan UNS (UNS Press).

Muzaki, A., \& Masjudin, M. (2019). Analisis Kemampuan Literasi Matematis Siswa. Mosharafa: Jurnal Pendidikan Matematika, 8(3), 493-502.

Nuraeni, Y., \& Afriansyah, E. A. (2016). Peningkatan Kemampuan

Pemahaman Matematis Siswa Melalui Pembelajaran Kooperatif Tipe Rotating Trio Exchange. Jurnal Inovasi Pendidikan Dasar, 1(2), 8594.

Puspitasari, I., Praja, E. S., \& Muhtarulloh, F. (2019). Pengembangan Bahan Ajar dengan Pendekatan Induktif untuk Meningkatkan

Kemampuan Representasi Matematis Siswa SMP. Mosharafa: Jurnal Pendidikan Matematika, 8(2), 307-318.

Ramziah, S. (2016). Peningkatan Kemampuan Representasi Matematis Siswa Kelas X2 SMAN 1 Gedung Meneng Menggunakan Bahan Ajar Matriks Berbasis Pendekatan Saintifik. Mosharafa: Jurnal Pendidikan Matematika, 5(2), 138-147.

Uno, H., B. (2011). Teori motivasi dan pengukurannya. Jakarta: PT Bumi Aksara.

Warti, E. (2016). Pengaruh Motivasi Belajar Siswa terhadap Hasil Belajar Matematika Siswa di SD Angkasa 10 Halim Perdana Kusuma Jakarta Timur. Mosharafa: Jurnal Pendidikan Matematika, 5(2), 177-185.

WilujengHestu, \& Yenni, Y. (2016). Multiple Mathematical
Representation Profile of Grade VIII Based on Multiple Intelligences. Proceeding of 3rd International Conference On Research, Implementation and Education of Mathematics and Science Yogyakarta, 16 - 17 May 2016. 357362.

Winkel, W. S. (1987). Psikologi Pengajaran. Jakarta: Gramedia.

Wolkfolk, A. (2007). Educational psychology (10rd ed). Boston: Pearson Education.

\section{Riwayat Hidup PenUlis}

Yenni, M. Pd.

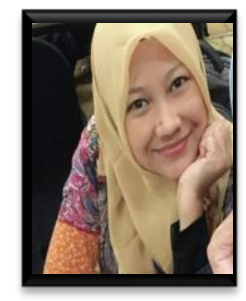

Peneliti lahir di Tegal Jawa Tengah pada tanggal 14 November 1979. Peneliti adalah pengajar di Program Studi Pendidikan Matematika Universitas Muhammadiyah Tangerang. Peneliti menamatkan S1 pada program studi Pendidikan Matematika di Universitas Pancasakti Tegal pada tahun 2003. Program Master bidang Pendidikan Matematika diperoleh di Universitas Pendidikan Indonesia Bandung pada tahun 2012.

Rika Sukmawati, M. Pd.

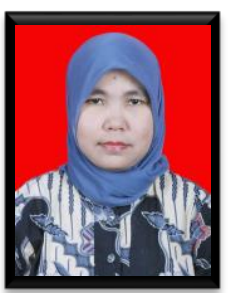

Lahir Jakarta, 21 Nopember 1975. Staf pengajar mata kuliah microteaching dan pembelajaran matematika SMP di Program Studi Pendidikan Matematika, FKIP, Universitas Muhammadiyah Tangerang. S1 di Universitas Indraprasta Jakarta Program studi Pendidikan Matematika lulus tahun 2006, S2 di Universitas Indraprasta Jakarta Program studi Pendidikan Matematika lulus tahun 2012. 